\title{
Actinomadura rudentiformis sp. nov., isolated from soil
}

\author{
Marilize le Roes and Paul R. Meyers \\ Department of Molecular and Cell Biology, University of Cape Town, Private Bag 1, \\ Rondebosch, 7701, Cape Town, South Africa
}

Correspondence

Paul R. Meyers

Paul.Meyers@uct.ac.za
Tuberculosis is the leading cause of death from a bacterial infectious disease (Viveiros et al., 2003; Sherman et al., 2001; McKinney et al., 2000; Kochi, 1991), killing 5000 people per day (World Health Organization, 2005). Furthermore, it is estimated that a third of the world's population is infected with the tuberculosis bacillus (Glyn Hewinson, 2005; Tran et al., 2004; World Health Organization, 2004; Zahrt \& Deretic, 2001; Bloom \& Murray, 1992; Kochi, 1991). South Africa had an incidence of 718 tuberculosis cases per 100000 people in the population in 2004 - the highest incidence among the 22 high-burden countries (World Health Organization, 2006). To compound the problem, it is estimated that $61 \%$ of all tuberculosis cases are attributable to patients who are also HIV-positive (50\% in 2003; World Health Organization, 2006).

According to Goodfellow (1989), the historical starting point for the genus Actinomadura was in 1894 when Vincent isolated and described the causative agent of 'Madura foot disease'. He proposed the name Streptothrix madurae, but the combination was considered to be invalid and the strain was subsequently transferred to the genus Nocardia and, eventually, to the genus Streptomyces (Goodfellow, 1989).

The GenBank/EMBL/DDBJ accession number for the $16 \mathrm{~S}$ rRNA gene sequence of strain $\mathrm{HMC1}^{\top}$ is $\mathrm{DQ} 285420$.

An extended neighbour-joining phylogenetic tree, based on 16S rRNA gene sequences, showing the position of strain $\mathrm{HMC}^{\top}$ amongst its phylogenetic neighbours is available as a supplementary figure in IJSEM Online.
With the introduction of cell-wall analysis, it was soon realized that the strain differed from members of the genus Streptomyces, and the genus Actinomadura was established by Lechevalier and Lechevalier in 1970 (Goodfellow, 1989; Mertz \& Yao, 1986). The genus soon became a 'dumping ground' for actinomycetes containing meso-diaminopimelic acid and having no characteristic sugars. The use of the polyphasic approach in bacterial taxonomy and, in particular, 16S rRNA gene sequence analysis, resulted in the clarification of the taxonomy of the genus, which at the time of writing comprises 34 recognized species and two subspecies. The type species is Actinomadura madurae (Euzéby, 2006; Quintana et al., 2003). The genus Actinomadura belongs to the family Thermomonosporaceae, which also includes Actinocorallia, Spirillospora and Thermomonospora (Zhang et al., 1998; Trujillo \& Goodfellow, 2003).

As part of a screening programme for antibiotic-producing actinomycetes, an actinomycete with unusual morphology was isolated from soil collected from the banks of the Gamka River, Swartberg Nature Reserve, Western Cape Province, South Africa.

Strain $\mathrm{HMCl}^{\mathrm{T}}$ was isolated on $\mathrm{MC}$ agar $\left(1^{-1}: 2.0\right.$ g glucose, $0.5 \mathrm{~g} \mathrm{NaNO}_{3}, 0.3 \mathrm{~g} \mathrm{~K}_{2} \mathrm{HPO}_{4}, 0.3 \mathrm{~g} \mathrm{KCl}, 0.3 \mathrm{~g} \mathrm{MgSO}_{4} .7 \mathrm{H}_{2} \mathrm{O}$, $0.01 \mathrm{~g} \mathrm{FeSO}_{4} .7 \mathrm{H}_{2} \mathrm{O}, \quad 0.001 \mathrm{~g} \quad \mathrm{CuSO}_{4} .5 \mathrm{H}_{2} \mathrm{O}, \quad 0.001 \mathrm{~g}$ $\mathrm{ZnSO}_{4} .7 \mathrm{H}_{2} \mathrm{O}, 0.001 \mathrm{~g} \mathrm{MnSO}_{4} .7 \mathrm{H}_{2} \mathrm{O}, 20.0 \mathrm{~g}$ agar; $\mathrm{pH} 7.4$; Nonomura \& Ohara, 1971) after the soil had been air-dried for 5 days at room temperature and then heat-treated at $120{ }^{\circ} \mathrm{C}$ for $1 \mathrm{~h}$. The treated soil $(0.1 \mathrm{~g})$ was suspended in 
$1 \mathrm{ml}$ sterile distilled water, vortexed for $1 \mathrm{~min}$, allowed to settle, serially diluted in sterile distilled water and then spread-plated in duplicate onto MC agar. The plates were incubated at $30^{\circ} \mathrm{C}$ for 21 days. Following isolation, strain $\mathrm{HMC1}^{\mathrm{T}}$ was maintained on yeast extract-malt extract agar (ISP 2; Shirling \& Gottlieb, 1966).

Antimicrobial activity was determined by using the sloppyagar overlay technique. The isolate was stab-inoculated into Difco Middlebrook 7H9 agar (Becton Dickinson) supplemented with $10 \mathrm{mM}$ glucose (albumin-dextrose-catalase supplement omitted), Czapek Solution agar (Atlas, 1993) and ISP 2 agar plates, in duplicate. The plates were incubated for 10 days at $30^{\circ} \mathrm{C}$ (and the duplicate set at $37^{\circ} \mathrm{C}$ ) and overlaid with $6 \mathrm{ml}$ Luria sloppy agar (Sambrook et al., 1989) containing the test bacterium. Antimicrobial activity was tested against Enterococcus faecium VanA (a vancomycinresistant clinical isolate), Mycobacterium aurum A + and Escherichia coli ATCC 25922.

For the organic solvent extraction of antibiotics, strain $\mathrm{HMCl}^{\mathrm{T}}$ was cultivated in $100 \mathrm{ml}$ ISP 2 and $100 \mathrm{ml}$ Nocardia medium $\left(1^{-1}: 1.0 \mathrm{~g}\right.$ glucose, $1.0 \mathrm{~g}$ glycerol, $1.0 \mathrm{~g}$ bacteriological peptone, $0.5 \mathrm{~g}$ beef extract; pH 7.0) (Tanaka et al., 1997) for 4 days at $30^{\circ} \mathrm{C}$ on a rocking shaker. The cultures were filtered separately through coffee filters $(1 \times 4$-sized filters; House of Coffees). The two samples of mycelial mass were combined and extracted successively with methanol, chloroform and hexane. The three solvent extracts were combined and concentrated 50 times by evaporating the solvent mixture and redissolving the residue in methanol. The culture filtrates were separately extracted with ethyl acetate and the extracts were combined and concentrated 50 times. Activity was tested against a range of Gram-positive and Gram-negative bacteria by bioautography (Betina, 1973). All tests on Mycobacterium tuberculosis $\mathrm{H} 37 \mathrm{Rv}^{\mathrm{T}}$ were performed in a Biosafety Level 3 laboratory.

The morphological characteristics of strain $\mathrm{HMCl}^{\mathrm{T}}$ were determined using standard methods (Locci, 1989). The isolate was grown on ISP 2 agar for 14 days at $30^{\circ} \mathrm{C}$ and the morphology observed under a light microscope and by cryoscanning electron microscopy.

Standard physiological tests (utilization of carbon sources, utilization of nitrogen sources, degradation of substrates, growth in the presence of inhibitors, and growth at different temperatures and $\mathrm{pH}$ values) were performed as described by Locci (1989). ISP media were prepared as described by Shirling \& Gottlieb (1966). Antibiotic resistance was determined by incorporation of the antibiotics into Bennett's medium agar plates (Atlas, 1993) at the recommended concentrations (Locci, 1989). Physiological characteristics were determined after growth at $30^{\circ} \mathrm{C}$ (unless otherwise stated) for the recommended incubation periods. All carbon sources used for carbonutilization tests were filter-sterilized and tested at the concentrations recommended by Locci (1989) and Shirling \& Gottlieb (1966).
Acid-fast staining (using $1 \%$ sulphuric acid for the decolourization step) and acid-alcohol-fast staining (with Ziehl-Neelsen stain) were performed using standard methods.

Freeze-dried cells for the chemotaxonomic tests were obtained from a $500 \mathrm{ml}$ ISP 2 culture of strain $\mathrm{HMCl}^{\mathrm{T}}$, which was cultivated on a rocking shaker at $30^{\circ} \mathrm{C}$ for 5 days. The diaminopimelic acid isomer and the whole-cell sugar pattern were determined using the method of Hasegawa et al. (1983), with the exception that freeze-dried cells were used instead of colonies from agar plates. The presence of mycolic acids was investigated by using the method of Minnikin et al. (1975).

The 16S rRNA gene of strain $\mathrm{HMC1}^{\mathrm{T}}$ was amplified by PCR using the universal bacterial primers $\mathrm{F} 1$ and $\mathrm{R} 5$; the amplified DNA was then subjected to the rapid identification method of Cook \& Meyers (2003). For the phylogenetic analysis, reference strains were chosen from the results of a BLAST analysis (Altschul et al., 1997) of the 16S rRNA gene sequence of strain $\mathrm{HMCl}^{\mathrm{T}}$. For the construction of phylogenetic trees, the software packages MEGA, version 2.1 (Kumar et al., 2001), and CLUSTAL_X, version 1.81 (Thompson et al., 1997), were used. Unrooted phylogenetic trees were constructed using the neighbour-joining (Saitou \& Nei, 1987), minimum-evolution and maximum-parsimony methods (Takahashi \& Nei, 2000) and were evaluated by bootstrap resampling (1000 replications).

Under cryo-scanning electron microscopy (Fig. 1), unusual rope-like or fibre-like growth was clearly visible. This unusual morphology is similar to that reported by Mertz \& Yao (1990) for Actinomadura fibrosa (96.68\% 16S rRNA gene sequence similarity to strain $\mathrm{HMCl}^{\mathrm{T}}$ by global alignment using DNAMAN software, version 4.13; Lynnon BioSoft). No sporangia and no spores were detected in the 14-day-old culture. The phenotypic characteristics are given in the species description.

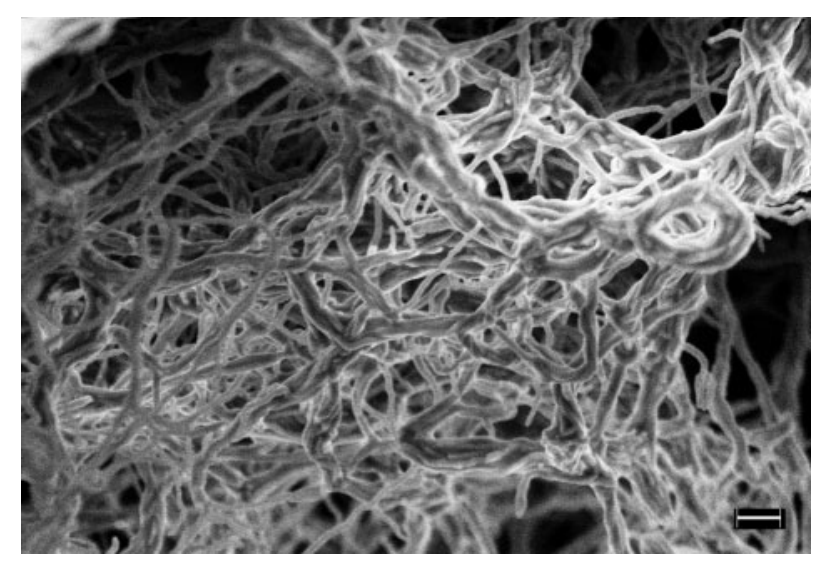

Fig. 1. Cryo-scanning electron micrograph of strain $\mathrm{HMC}^{\top}$ grown on ISP 2 at $30^{\circ} \mathrm{C}$ for 14 days. The unusual rope-like mycelium is clearly visible. Bar, $3 \mu \mathrm{m}$. 
The rapid identification technique of Cook \& Meyers (2003) placed strain $\mathrm{HMCl}^{\mathrm{T}}$ within a group containing Actinocorallia, Actinomadura, Saccharothrix and Spirillospora. The chemotaxonomic characteristics of strain $\mathrm{HMCl}^{\mathrm{T}}$, however, were most consistent with those of members of the genus Actinomadura. mesoDiaminopimelic acid was detected in the peptidoglycan of strain $\mathrm{HMCl}^{\mathrm{T}}$ and the whole-cell hydrolysates yielded galactose, glucose, madurose, mannose and ribose. No mycolic acids were detected in the cell wall, and the isolate was non-acid-fast and non-acid-alcohol-fast.

A 1433 bp 16S rRNA gene sequence was obtained for strain $\mathrm{HMCl}^{\mathrm{T}}$. A BLAST search showed that $\mathrm{HMCl}^{\mathrm{T}}$ was most closely related to Actinomadura fulvescens DSM $43923^{\mathrm{T}}$ (98.0\%), Actinomadura hibisca DSM 44148 ${ }^{\mathrm{T}}$ (97.0\%), Actinomadura nitritigenes DSM $44137^{\mathrm{T}} \quad(96.7 \%)$, Actinomadura fibrosa ATCC $49459^{\mathrm{T}}$ (96.7\%), Spirillospora albida NBRC $12248^{\mathrm{T}}$ (96.4\%), Actinomadura meyerae A288 ${ }^{\mathrm{T}}(96.2 \%)$ and Actinomadura viridis DSM $43175^{\mathrm{T}}$ (96.2\%) (note that these similarity values were calculated from pairwise global alignments using DNAMAN and are not the BLAST-analysis figures). A neighbour-joining phylogenetic tree based on 16S rRNA gene sequences, showing Actinomadura species, the type species of the genera Actinocorallia and Spirillospora, and strain $\mathrm{HMC1}^{\mathrm{T}}$ (see Supplementary Fig. S1 available in IJSEM Online) showed that strain $\mathrm{HMCl}^{\mathrm{T}}$ clustered with Spirillospora albida, Actinomadura fulvescens, Actinomadura nitritigenes and Actinomadura fibrosa. Even though Spirillospora albida appears to be the closest phylogenetic neighbour of strain $\mathrm{HMC1}^{\mathrm{T}}$ (Supplementary Fig. S1), the clear difference in morphology (lack of sporangia in $\mathrm{HMCl}^{\mathrm{T}}$ ) and the low level of $16 \mathrm{~S}$ rRNA gene sequence similarity (96.4\%) clearly differentiate the two strains from each other. Furthermore, when a smaller number of sequences were used in the construction of the phylogenetic tree (Fig. 2), strain $\mathrm{HMCl}^{\mathrm{T}}$ clustered with Actinomadura fulvescens (the top BLAST hit) rather than Spirillospora albida. A comparison of the phenotypic characteristics of strain $\mathrm{HMCl}^{\mathrm{T}}$ and its phylogenetic neighbours is shown in Table 1. It is clear from these data that strain $\mathrm{HMCl}^{\mathrm{T}}$ is phenotypically different from the most closely related Actinomadura species and Spirillospora albida.

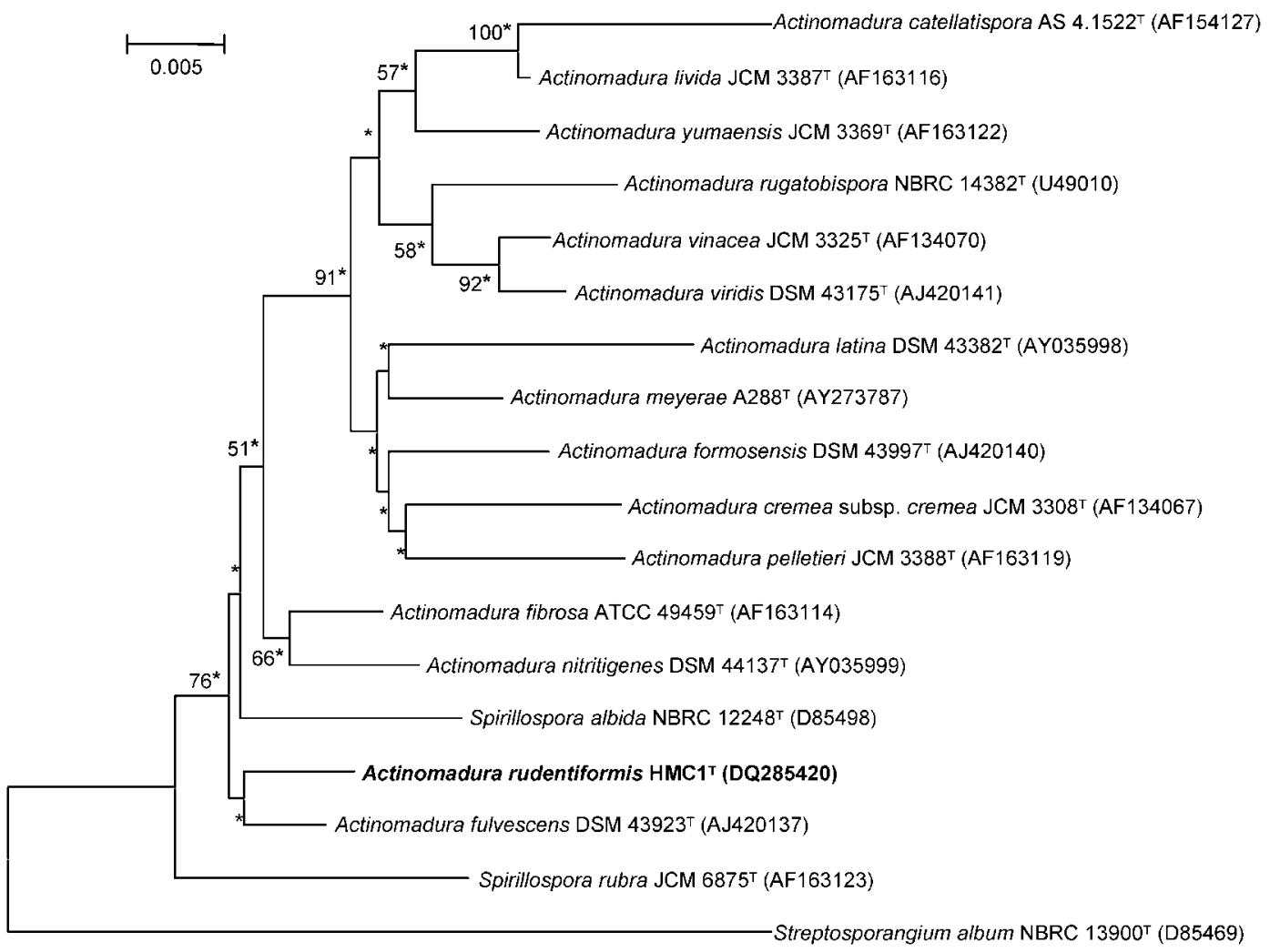

Fig. 2. Unrooted neighbour-joining phylogenetic tree, based on 16S rRNA gene sequences, showing the position of strain $\mathrm{HMC}^{\top}$ amongst its phylogenetic neighbours. The $16 \mathrm{~S}$ rRNA gene sequence of Streptosporangium album NBRC $13900^{\top}$ was used as an outgroup. All sequences were edited to the longest common region (1395 bp). GenBank accession numbers are given in parentheses. Numbers at nodes show bootstrap percentages of 1000 replications. Asterisks indicate the clades that were conserved when neighbour-joining, minimum-evolution and maximum-parsimony methods were used to construct phylogenetic trees. Bar, 0.005 nucleotide substitutions per position. 
Table 1. Phenotypic characteristics that differentiate strain $\mathrm{HMC} 1^{\top}$ from related type strains

Strains: 1, $\mathrm{HMCl}^{\mathrm{T}}$; 2, Actinomadura fulvescens (data from Trujillo \& Goodfellow, 2003); 3, Actinomadura nitritigenes DSM 44137 ${ }^{\mathrm{T}}$ (Lipski \& Altendorf, 1995); 4, Actinomadura fibrosa ATCC $49459^{\mathrm{T}}$ (Mertz \& Yao, 1990); 5, Spirillospora albida NBRC 12248 ${ }^{\mathrm{T}}$ (Wink, 2001). ND, Not determined.

\begin{tabular}{|c|c|c|c|c|c|}
\hline Characteristic & 1 & 2 & 3 & 4 & 5 \\
\hline Growth on ISP $2^{*}$ & $\begin{array}{l}\text { SM: cream (extensive } \\
\text { wrinkling); AM: - }\end{array}$ & $\begin{array}{l}\text { SM: yellow; AM: -; } \\
\text { DP: yellow }\end{array}$ & $\begin{array}{l}\text { SM: colourless; } \\
\text { AM: brown }\end{array}$ & $\begin{array}{l}\text { SM: brown; AM: } \\
\text { white; DP: brown }\end{array}$ & $\begin{array}{l}\text { SM: beige; AM: } \\
\text { white; DP: - }\end{array}$ \\
\hline Growth on ISP $4^{*}$ & SM: white; AM: - & Does not grow & $\begin{array}{l}\text { SM: brown; } \\
\text { AM: white }\end{array}$ & SM: brown; AM: pink & $\begin{array}{l}\text { SM: beige; } \\
\text { AM: white }\end{array}$ \\
\hline Production of sporangia & - & - & - & - & + \\
\hline \multicolumn{6}{|l|}{ Degradation of: } \\
\hline Gelatin & + & + & ND & ND & - \\
\hline L-Tyrosine & - & - & ND & + & + \\
\hline \multicolumn{6}{|l|}{$\begin{array}{l}\text { Utilization of sole } \\
\text { carbon sources: }\end{array}$} \\
\hline$(+)$-D-Cellobiose & + & + & + & ND & - \\
\hline myo-Inositol & + & ND & ND & ND & - \\
\hline$(-)$-D-Lactose & + & $33 \% \dagger$ & - & ND & ND \\
\hline (-)-D-Mannitol & + & - & ND & ND & + \\
\hline$(+)$-D-Melibiose & + & - & ND & ND & ND \\
\hline Raffinose & + & - & ND & ND & - \\
\hline$(+)$-L-Rhamnose & + & $33 \% \dagger$ & + & ND & - \\
\hline$(+)$-D-Xylose & + & + & + & $\mathrm{ND}$ & - \\
\hline \multicolumn{6}{|l|}{$\begin{array}{l}\text { Utilization of sole } \\
\text { nitrogen sources: }\end{array}$} \\
\hline L-Arginine & + & - & ND & ND & - \\
\hline L-Phenylalanine & + & - & ND & ND & ND \\
\hline
\end{tabular}

${ }^{\star} \mathrm{AM}$, aerial mycelium; DP, diffusible pigment; SM, substrate mycelium.

$\dagger$ Percentage of strains within the group that are positive in the test.

Strain $\mathrm{HMCl}^{\mathrm{T}}$ degraded adenine and xylan, whereas Actinomadura fulvescens did not. Strain $\mathrm{HMC1}^{\mathrm{T}}$ utilized (-)-D-mannitol, (+)-D-melibiose and raffinose as sole carbon sources, and used L-arginine and L-phenylalanine as sole nitrogen sources; none of these was used by Actinomadura fulvescens. The growth characteristics of these two strains on ISP 2 and ISP 4 also differed (Table 1) (information on Actinomadura fulvescens was obtained from Trujillo \& Goodfellow, 2003).

There are five major differences between strain $\mathrm{HMCl}^{\mathrm{T}}$ and Actinomadura nitritigenes, including differences in growth characteristics on ISP 2 and ISP 4; strain $\mathrm{HMC1}^{\mathrm{T}}$ degraded adenine and xylan but not hypoxanthine, and utilized $(-)$ D-lactose as a sole carbon source. There are also five major differences between strain $\mathrm{HMCl}^{\mathrm{T}}$ and Actinomadura fibrosa, including differences in growth characteristics on ISP 2 and ISP 4; Actinomadura fibrosa reduces nitrate and degrades hypoxanthine and starch, but does not degrade adenine (Mertz \& Yao, 1990).

There are ten major differences between strain $\mathrm{HMC1}^{\mathrm{T}}$ and Spirillospora albida, including differences in growth characteristics on ISP 2 and ISP 4: Spirillospora albida produces sporangia, degrades L-tyrosine (but not gelatin), cannot utilize (+)-D-cellobiose, myo-inositol, raffinose, $(+)$-Lrhamnose and $(+)$-D-xylose as sole carbon sources, and cannot utilize L-arginine as a sole nitrogen source (Wink, 2001).

On the basis of the phenotypic and genotypic data presented, it is proposed that strain $\mathrm{HMCl}^{\mathrm{T}}$ represents a novel species within the genus Actinomadura, for which the name Actinomadura rudentiformis sp. nov. is proposed.

\section{Description of Actinomadura rudentiformis sp. nov.}

Actinomadura rudentiformis (ru.den.ti.for'mis. L. masc. n. rudens rope; L. adj. suffix -formis -like, in the shape of; N.L. fem. adj. rudentiformis shaped like a rope).

During incubation for 14 days on oatmeal agar (ISP 3) supplemented with $0.1 \%$ yeast extract, forms creamcoloured substrate mycelium, with sparse white aerial mycelium. Wrinkled, cream-coloured substrate mycelium forms on ISP 2, but no sporulation occurs. White substrate mycelium forms on inorganic salts-starch agar (ISP 4), but 
no sporulation occurs. No diffusible pigment is produced on glycerol-asparagine agar (ISP 5) and melanin production on peptone-yeast extract-iron agar (ISP 6) or tyrosine agar (ISP 7) is not observed. Very strong antibiosis is exhibited against $M$. aurum $\mathrm{A}+$ and weak antibiosis is shown against Enterococcus faecium VanA (vancomycin-resistant) in agar overlays. Bioautographic analysis of organic solvent extracts of cell mass shows moderate antibiosis against $M$. aurum $\mathrm{A}+$, Mycobacterium bovis BCG (Tokyo) and M. tuberculosis $\mathrm{H} 37 \mathrm{Rv}^{\mathrm{T}}$. Catalase-positive, oxidase-negative and Grampositive. Grows in the presence of $0.3 \%$ 2-phenylethanol, weakly in the presence of $0.0001 \%$ crystal violet, but not in the presence of $4 \% \mathrm{NaCl}, 0.1 \%$ phenol or sodium azide $(0.01 \%)$. Growth occurs in the presence of the following antibiotics ( $\mu \mathrm{g} \mathrm{ml}^{-1}$, unless indicated otherwise): kanamycin (10), neomycin (50), oleandomycin (100), penicillin G $\left(10 \mathrm{IU} \mathrm{ml}^{-1}\right.$ ), rifampicin (50) and tobramycin (50). Growth is not observed in the presence of the following antibiotics $\left(\mu \mathrm{g} \mathrm{ml}^{-1}\right)$ : cephaloridine (100), gentamicin (100), lincomycin (100), streptomycin (100) and vancomycin (50). Growth occurs at 30,37 and $45^{\circ} \mathrm{C}$, but not at $4{ }^{\circ} \mathrm{C}$ or $\mathrm{pH} 4.3$. Utilizes DL- $\alpha$-amino-n-butyric acid, Larginine, L-cysteine, L-histidine, L-hydroxyproline, Lmethionine, L-phenylalanine, potassium nitrate, L-serine, $\mathrm{L}$-threonine and L-valine as sole nitrogen sources. Utilizes adonitol, $(+)$-D-cellobiose, $(-)$-D-fructose, $(+)$-D-galactose, $(+)$-D-glucose, myo-inositol, inulin, $(-)$-D-lactose, $(-)$-D-mannitol, (+)-D-mannose, (+)-D-melibiose, raffinose, $(+)$-L-rhamnose, sucrose, trehalose and $(+)$-Dxylose as sole carbon sources; $(+)$-L-arabinose, $(+)$-Dmelezitose, ( - -D-ribose, salicin, sodium acetate $(0.1 \%)$ and xylitol are weakly utilized. Sodium citrate $(0.1 \%)$ is not utilized. $\mathrm{H}_{2} \mathrm{~S}$ production and nitrate reduction do not occur. Lecithinase, lipase and protease activities are not observed on egg-yolk agar. Hippurate is hydrolysed, but pectin is not. Degrades adenine, aesculin, arbutin, casein, cellulose, gelatin, Tween 80 and xylan; guanine and starch are weakly degraded. Allantoin, hypoxanthine, L-tyrosine, urea and xanthine are not degraded.

The type strain, $\mathrm{HMCl}^{\mathrm{T}}\left(=\mathrm{DSM} 44962^{\mathrm{T}}=\mathrm{NRRL}\right.$ B$24458^{\mathrm{T}}$ ), was isolated from soil collected from the banks of the Gamka River in the Swartberg Nature Reserve, Western Cape Province, South Africa.

\section{Acknowledgements}

We are grateful to Di James for DNA sequencing, Miranda Waldron of the Electron Microscope Unit, University of Cape Town, for help with scanning electron microscopy, Professor Dr Hans G. Trüper for assistance with Latin in deriving the specific epithet for strain $\mathrm{HMCl}^{\mathrm{T}}$, and Professor Lafras Steyn for use of the Biosafety Level 3 laboratory in the Institute of Infectious Diseases and Molecular Medicine at the University of Cape Town. M. le R. held a Scarce Skills Scholarship from the National Research Foundation. P. R. M. is the recipient of research grants from the Medical Research Council of South Africa and the University Research Committee (University of Cape Town).

\section{References}

Altschul, S. F., Madden, T. L., Schäffer, A. A., Zhang, J., Zhang, Z., Miller, W. \& Lipman, D. J. (1997). Gapped BLAST and PSI-BLAST: a new generation of protein database search programs. Nucleic Acids Res 25, 3389-3402.

Atlas, R. M. (1993). Handbook of Microbiological Media. Edited by L. C. Parks. Boca Raton, FL: CRC Press.

Betina, V. (1973). Bioautography in paper and thin-layer chromatography and its scope in the antibiotic field. J Chromatogr 78, 41-51.

Bloom, B. R. \& Murray, C. J. L. (1992). Tuberculosis: commentary on a reemergent killer. Science 257, 1055-1064.

Cook, A. E. \& Meyers, P. R. (2003). Rapid identification of filamentous actinomycetes to the genus level using genus-specific $16 \mathrm{~S}$ rRNA gene restriction fragment patterns. Int J Syst Evol Microbiol 53, 1907-1915.

Euzéby, J. P. (2006). List of prokaryotic names with standing in nomenclature. http://www.bacterio.cict.fr/

Goodfellow, M. (1989). Maduromycetes. In Bergey's Manual of Systematic Bacteriology, vol. 4, pp. 2509-2551. Edited by S. T. Williams, M. E. Sharpe \& J. G. Holt. Baltimore: Williams \& Wilkins.

Hasegawa, T., Takizawa, M. \& Tanida, S. (1983). A rapid analysis for chemical grouping of aerobic actinomycetes. J Gen Appl Microbiol 29, 319-322.

Glyn Hewinson, R. (2005). TB vaccines for the world. Tuberculosis 85, 1-6.

Kochi, A. (1991). The global tuberculosis situation and the new control strategy of the World Health Organization. Tubercle 72, 1-6.

Kumar, S., Tamura, K., Jakobsen, I. B. \& Nei, M. (2001). MEGA2: molecular evolutionary genetics analysis software. Bioinformatics 17, 1244-1245.

Lechevalier, M. P. \& Lechevalier, H. (1970). Chemical composition as a criterion in the classification of aerobic actinomycetes. Int J Syst Bacteriol 20, 435-443.

Lipski, A. \& Altendorf, K. (1995). Actinomadura nitritigenes sp. nov., isolated from experimental biofilters. Int J Syst Bacteriol 45, 717-723.

Locci, R. (1989). Streptomycetes and related genera. In Bergey's Manual of Systematic Bacteriology, vol. 4, pp. 2451-2508. Edited by S. T. Williams, M. E. Sharpe \& J. G. Holt. Baltimore: Williams \& Wilkins.

McKinney, J. D., Honer zu Bentrup, K., Muñoz-Elias, E. J., Miczak, A., Chen, B., Chan, W. T., Swenson, D., Sacchettini, J. C., Jacobs, W. R., Jr \& Russell, D. G. (2000). Persistence of Mycobacterium tuberculosis in macrophages and mice requires the glyoxylate shunt enzyme isocitrate lyase. Nature 406, 735-738.

Mertz, F. P. \& Yao, R. C. (1986). Actinomadura oligospora sp. nov., the producer of a new polyether antibiotic. Int J Syst Bacteriol 36, 179-182.

Mertz, F. P. \& Yao, R. C. (1990). Actinomadura fibrosa sp. nov. isolated from soil. Int J Syst Bacteriol 40, 28-33.

Minnikin, D. E., Alshamaony, L. \& Goodfellow, M. (1975). Differentiation of Mycobacterium, Nocardia, and related taxa by thin-layer chromatographic analysis of whole-organism methanolysates. J Gen Microbiol 88, 200-204.

Nonomura, H. \& Ohara, Y. (1971). Distribution of actinomycetes in soil. VIII. Green spore group of Microtetraspora, its preferential isolation and taxonomic characteristics. J Ferment Technol 49, 1-7.

Quintana, E. T., Trujillo, M. E. \& Goodfellow, M. (2003). Actinomadura mexicana sp. nov. and Actinomadura meyerii sp. nov., two novel soil sporoactinomycetes. Syst Appl Microbiol 26, 511-517. 
Saitou, N. \& Nei, M. (1987). The neighbor-joining method: a new method for reconstructing phylogenetic trees. Mol Biol Evol 4, 406-425.

Sambrook, J., Fritsch, E. F. \& Maniatis, T. (1989). Bacterial media, antibiotics and bacterial strains. In Molecular Cloning: a Laboratory Manual, 2nd edn, pp. A.1-A.13. Cold Spring Harbor, NY: Cold Spring Harbor Laboratory.

Sherman, D. R., Voskuil, M., Schnappinger, D., Liao, R., Harrell, M. I. \& Schoolnik, G. K. (2001). Regulation of the Mycobacterium tuberculosis hypoxic response gene encoding $\alpha$-crystallin. Proc Natl Acad Sci U S A 98, 7534-7539.

Shirling, E. B. \& Gottlieb, D. (1966). Methods for characterization of Streptomyces species. Int J Syst Bacteriol 16, 313-340.

Takahashi, K. \& Nei, M. (2000). Efficiencies of fast algorithms of phylogenetic inference under the criteria of maximum parsimony, minimum evolution, and maximum likelihood when a large number of sequences are used. Mol Biol Evol 17, 1251-1258.

Tanaka, Y., Gräefe, U., Yazawa, K., Ritzau, M. \& Mikami, Y. (1997). Nocardicyclins A and B: new anthracycline antibiotics produced by Nocardia pseudobrasiliensis. J Antibiot 50, 822-827.

Thompson, J. D., Gibson, T. J., Plewniak, F., Jeanmougin, F. \& Higgins, D. G. (1997). The CLUSTAL_X windows interface: flexible strategies for multiple sequence alignment aided by quality analysis tools. Nucleic Acids Res 25, 4876-4882.
Tran, T., Saheba, E., Arcerio, A. V., Chavez, V., Li, Q.-Y., Martinez, L. E. \& Primm, T. P. (2004). Quinones as antimycobacterial agents. Bioorg Med Chem 12, 4809-4813.

Trujillo, M. E. \& Goodfellow, M. (2003). Numerical phenetic classification of clinically significant aerobic sporoactinomycetes and related organisms. Antonie van Leeuwenhoek 84, 39-68.

Viveiros, M., Leandro, C. \& Amaral, L. (2003). Mycobacterial efflux pumps and chemotherapeutic implications. Int J Antimicrob Agents 22, 274-278.

World Health Organization (2004). Tuberculosis, Fact Sheet No. 104. http://www.who.int/mediacentre/factsheets/fs104/en/print.html

World Health Organization (2005). TB/HIV - Facts at a Glance. http://www.stoptb.org/news/archives/iacxv/assets/InfoPack/1GB.pdf

World Health Organization (2006). Global Tuberculosis Control: Surveillance, Planning, Financing, WHO report 2006. http://www.who.int/tb/ publications/global_report/2006/pdf/full_report_correctedversion.pdf

Wink, J. (2001). The Actinomycetales. An Order in the Class of Actinobacteria Important to the Pharmaceutical Industry - Electronic Manual. Frankfurt: Aventis Pharma.

Zahrt, T. C. \& Deretic, V. (2001). Mycobacterium tuberculosis signal transduction system required for persistent infections. Proc Natl Acad Sci U S A 98, 12706-12711.

Zhang, Z., Wang, Y. \& Ruan, J. (1998). Reclassification of Thermomonospora and Microtetraspora. Int J Syst Bacteriol 48, 411-422. 